\title{
Pollution reduction investigation of soil and nutritional plants contaminated with lead using natural zeolite
}

\author{
Reda Adomaitytè, Agnè Kazlauskienè \\ Vilnius Gediminas Technical University, Faculty of Environmental Engineering, Saulètekio av. 11, Vilnius 10223, Lithuania
}

\begin{abstract}
Transport system is one of the heavy metals occurrence sources in the environment in Lithuania. Heavy metals have a negative toxic impact on all living organisms, such as: flora, fauna, and human beings. Increased heavy metal solubility reduces the solubility of nutrients, resulting in a decrease of plant available nutrients. The zeolite is used for environmental purposes. The research results of natural zeolite clinoptilolite inserted to the lead-polluted soil nutrients effect on test plants (lettuce (Lactuca sativa) and garden cress (Lepidium sativum L.)) ability to absorb and reduce the lead concentration in the soil are presented in the paper. Garden cress accumulates lead about $10-12 \%$ more than lettuce. It is appropriate to insert not more than $20 \%$ zeolite according to amount of the soil, in order to reduce lead concentration in polluted soils and food crops.
\end{abstract}

Keywords: Lactuca sativa, lead, Lepidium sativum L., natural zeolite, soil pollution.

\section{Introduction}

Environmental pollution by heavy metals (HM) is an important global problem, as the total Korte index indicates the risk to life, health and heredity; heavy metals are the leaders among the environmental problems. Transport system is one of the heavy metals occurrence sources in the environment in Lithuania. The amounts of heavy metals $(\mathrm{Cr}, \mathrm{Cd}, \mathrm{Pb}, \mathrm{Ni}, \mathrm{Cu}, \mathrm{Zn})$ exceeding the maximum concentration get into the roadside soil during automobile transport exploitation [1-4].

Under natural conditions, heavy metals are important elements for plant vital functions and in low concentrations are involved in plant nutrition circuits [5]. Some HM as microelements are essential for plants and animals, but they become toxic if higher concentration is accumulated. Heavy metals have a negative toxic impact on all living organisms, such as: flora, fauna, and human beings [6-7]. Plant roots, reproductive characteristics, food and feed crops weaken because of heavy metals. Increased heavy metal solubility reduces the solubility of nutrients, resulting in a decrease of plant available nutrients. The plants begin to appropriate HM similar to nutrients, ultimately weakening their growth. Heavy metals inhibit the growth of plants, reducing their productivity, and a large amount of heavy metals can get in the human body together with the vegetable food [8-9]. Heavy metals are harmful not only to plants or animals, but also to human beings. Different HM can affect the central nervous system and various organs, and can cause different diseases. Heavy metals can cause not only endemic diseases, but also affect the growth of biological organisms and developmental disorders, weaken the immune system, and damage reproductive functions. Heavy metals often have carcinogenic and mutagenic influence. It is believed that the influence of heavy metals for all vitality will grow even more in the future [10-11]. Heavy metals migrate while entering the soil or surface water, they may get into the ground water, sink at the bottom of the pond. Heavy metals can accumulate via migration from one natural system to another, making a negative impact on living systems of vital organisms [12-14].Soil contamination can be not observed for some time, on the contrary to air or water pollution, because the human being is not in contact with the soil as close as the air or water. The negative changes cannot occur immediately because of buffer nature of the soil, its properties or composition [15-16].

Adults and older children get lead mostly with food and water [17]. Soil fungi and bacteria assimilating nitrogen from soil are the most sensitive to the effects of lead. The accumulated in the soil lead of technological origin negatively affects plants, reduces the fertility of nutrients and feeding crops, accumulates in vegetables and garden cultural roots [18-19].

Corresponding author: Reda Adomaitytè. E-mail address: reda.adomaityte@stud.vgtu.lt

http://dx.doi.org/10.3846/enviro.2014.001

(C) 2014 The Authors. Published by VGTU Press. This is an open-access article distributed under the terms of the Creative Commons Attribution License, which permits unrestricted use, distribution, and reproduction in any medium, provided the original author and source are credited. 
Zeolite is one of the means used in environmental protection, reducing HM concentration in soil and improving biometric indicators of nutritional plants. Zeolite was chosen for the research. The zeolites have a number of useful features due to their specific structure. Adsorption is one of the main applications of the zeolite., Zeolites as adsorbents are used as initial reagents for separation of the products during the reactions; so zeolite can be used to remove HM, radionuclides, petroleum products, and other pollutants [20-22]. Zeolites can adsorb about $90 \%$ of the pollutants, according to the zeolite particle size, pollutant concentration and filtration rate [23]. Zeolite is used as an effective fertilizer. The use of mineral fertilizers to increase crop yield is closely associated with diffusive pollution. Foreign and Lithuanian scientists have investigated zeolite properties influence to grass crop harvest increase, nitrogen leaching decrease and other parameters [2427].

\section{Experimental}

\subsection{Research materials and methods}

The purpose of the research is to determine the influence of natural zeolite of (of 3-5 mm fraction) inserted in the leadcontaminated soil to lead concentrations change in soil and food plants.

Investigational objects: popular nutritional plants in Lithuania, such as: lettuce (Lactuca sativa) and garden cress (Lepidium sativum L.) that are grown in both field and greenhouse conditions were taken as the samples for the research.

In addition, garden cress (Lepidium sativum L.) was the test-object [28].

The natural zeolite (clinoptylolite) was selected for the research due a number of its unique structural and functional properties. The zeolites used for lawn preparation add the following characteristics to the soil: reduce soil trample, deeply aerate the soil and plant roots, improve water permeability up to the area of roots, retain the optimum amount of water (up to $35 \%$ of the zeolite mass), keep toxic substances preventing them from been discharged into the environment, considerably reduce washing out of fertilizers to the environment in this way reducing the contamination of ground waters, and, based on plants' needs, gradually convey nutritive agrochemically useful substances $\left(\mathrm{Na}^{+}, \mathrm{Ca}^{2+}, \mathrm{K}^{+}, \mathrm{Mg}^{2+}\right.$ and others) and water to them, ensure a perfect level of cation $\left(\mathrm{Na}^{+}, \mathrm{Ca}^{2+}, \mathrm{K}^{+}\right)$exchange $(0.9-1.5 \mathrm{~g}$-eqv./g), and encourage the propagation of useful microorganisms. This results in the growth of stronger plants resistant to adverse environmental factors (stress). The zeolite is used in 3-5 $\mathrm{mm}$ fractions since this size is optimum when zeolite is used for environmental purposes [29].

The soil of the following composition was used for the research: nitrogen $\left(\mathrm{NH}_{4}+\mathrm{NO}_{3}\right)-100 \mathrm{mg} / \mathrm{l}$; phosphorus $\left(\mathrm{P}_{2} \mathrm{O}_{5}\right)-$ $50 \mathrm{mg} / \mathrm{l}$; potassium $\left(\mathrm{K}_{2} \mathrm{O}\right)-300 \mathrm{mg} / \mathrm{l}$; calcium $(\mathrm{CaO})-300 \mathrm{mg} / \mathrm{l}$; magnesium $(\mathrm{MgO})-80 \mathrm{mg} / \mathrm{l}$; ferrum $\left(\mathrm{Fe}_{2} \mathrm{O}_{3}\right)-800 \mathrm{mg} / \mathrm{l}$. Soil for the research was acquired at a company and prepared according to IST 2292587-001:1999.

$\mathrm{Pb}\left(\mathrm{NO}_{3}\right)_{2}$ salt was used for soil pollution, as lead $(\mathrm{Pb})$ is its integral part. Heavy metal $\mathrm{Pb}$ is typical roadside pollutant, preeminent during automotive vehicle exploitation [30].

$2 \mathrm{~g}$ of lettuce and $2 \mathrm{~g}$ of garden cress seeds were sown in plastic pots with $1 \mathrm{~kg}$ of lead-polluted soil by inserting an appropriate amount of zeolite. Two lead $(\mathrm{Pb})$ concentrations (respectively $100 \mathrm{mg} / \mathrm{kg}$ and $150 \mathrm{mg} / \mathrm{kg}$ ) were inserted in soil in the form of watering during the research.

Three different clinoptilolite quantities, mixed into the contaminated with $\mathrm{Pb}$ soil, were used in the research:

$1 . \mathbf{1 0} \%$ of zeolite from the soil volume was inserted in the soil,

$2 . \mathbf{2 0} \%$ of zeolite from the soil volume was inserted in the soil,

$3 . \mathbf{3 0} \%$ of zeolite from the soil volume was inserted in the soil.

For the comparison (control) of the results, exploratory nutritional plant species were sown in soil, polluted with lead concentrations, but without introducing zeolite (0\%) (Table 1).

Table 1. The composition of soil and zeolite mixtures used for the investigation

\begin{tabular}{|c|c|c|c|c|}
\hline Mixture number & Name of test plant & Amount of soil (kg) & $\begin{array}{l}\mathrm{Pb} \text { concentration } \\
\text { in soil }(\mathrm{mg} / \mathrm{kg})\end{array}$ & $\begin{array}{c}\text { Amount of zeolite in soil } \\
(\%, g)\end{array}$ \\
\hline 1. & Lactuca sativa & $1 \mathrm{~kg}$ & $100 \mathrm{mg} / \mathrm{kg}$ & $10 \%(100 \mathrm{~g})$ \\
\hline 2. & Lactuca sativa & $1 \mathrm{~kg}$ & $100 \mathrm{mg} / \mathrm{kg}$ & $20 \%(200 \mathrm{~g})$ \\
\hline 3. & Lactuca sativa & $1 \mathrm{~kg}$ & $100 \mathrm{mg} / \mathrm{kg}$ & $30 \%(300 \mathrm{~g})$ \\
\hline 4. & Lactuca sativa & $1 \mathrm{~kg}$ & $150 \mathrm{mg} / \mathrm{kg}$ & $10 \%(100 \mathrm{~g})$ \\
\hline 5. & Lactuca sativa & $1 \mathrm{~kg}$ & $150 \mathrm{mg} / \mathrm{kg}$ & $20 \%(200 \mathrm{~g})$ \\
\hline 6. & Lactuca sativa & $1 \mathrm{~kg}$ & $150 \mathrm{mg} / \mathrm{kg}$ & $30 \%(300 \mathrm{~g})$ \\
\hline 7. & Lepidium sativum L. & $1 \mathrm{~kg}$ & $100 \mathrm{mg} / \mathrm{kg}$ & $10 \%(100 \mathrm{~g})$ \\
\hline 8. & Lepidium sativum L. & $1 \mathrm{~kg}$ & $100 \mathrm{mg} / \mathrm{kg}$ & $20 \%(200 \mathrm{~g})$ \\
\hline 9. & Lepidium sativum L. & $1 \mathrm{~kg}$ & $100 \mathrm{mg} / \mathrm{kg}$ & $30 \%(300 \mathrm{~g})$ \\
\hline 10. & Lepidium sativum L. & $1 \mathrm{~kg}$ & $150 \mathrm{mg} / \mathrm{kg}$ & $10 \%(100 \mathrm{~g})$ \\
\hline 11. & Lepidium sativum L. & $1 \mathrm{~kg}$ & $150 \mathrm{mg} / \mathrm{kg}$ & $20 \%(200 \mathrm{~g})$ \\
\hline 12. & Lepidium sativum L. & $1 \mathrm{~kg}$ & $150 \mathrm{mg} / \mathrm{kg}$ & $30 \%(300 \mathrm{~g})$ \\
\hline \multicolumn{5}{|l|}{ Control } \\
\hline 13. & Lactuca sativa & $1 \mathrm{~kg}$ & $100 \mathrm{mg} / \mathrm{kg}$ & $0 \%(0 \mathrm{~g})$ \\
\hline 14. & Lactuca sativa & $1 \mathrm{~kg}$ & $150 \mathrm{mg} / \mathrm{kg}$ & $0 \%(0 \mathrm{~g})$ \\
\hline 15. & Lepidium sativum L. & $1 \mathrm{~kg}$ & $100 \mathrm{mg} / \mathrm{kg}$ & $0 \%(0 \mathrm{~g})$ \\
\hline 16. & Lepidium sativum L. & $1 \mathrm{~kg}$ & $150 \mathrm{mg} / \mathrm{kg}$ & $0 \%(0 \mathrm{~g})$ \\
\hline
\end{tabular}


Both the experimental and the control plants were grown under identical conditions, i.e. at the same temperature and lighting, were watered with identical amounts of water and at the same time. The experimental plants were grown in the northern part of the laboratory without being exposed to direct sunlight, i.e. unfavourable ecological conditions were chosen. The bottom of every plant pot had holes to ensure natural water run-off and prevent excess accumulation of water in soil [29]. The research was carried out for six weeks, whereas during this time the nutritional plants are either eaten or lose their nutritional qualities.

\subsection{Chemical analysis}

The experimental research was carried out according formed research methods of applied methodology by the other researchers $[3,5,30,31]$. The samples of soil, polluted with heavy metal lead and nutritional food (lettuce and garden cress) were taken from the third research week (until acquired sufficient biomass) to the end of the research (sixth week) (Fig. 1). 64 samples of soil with removed natural zeolite and 32 samples of lettuce, and 32 samples of garden cress samples were analyzed there.

The samples were previously dried to constant weight, and then burned in a kiln and mineralized in digester in order to determine the change of $\mathrm{Pb}$ concentration in soil with eliminated zeolite and in nutritional plants. The burning process of dried samples located in crucibles was going on at $450^{\circ} \mathrm{C}$ for 1.5 hours. The samples of burnt soil and burnt nutrition were sieved through $1 \mathrm{~mm}$ sieve before the process of mineralization. The samples were weighed for $0.5 \mathrm{~g}$ of each soil or nutritional plant sample and placed in the mineralization cruets. $5 \mathrm{ml}$ of $\mathrm{HNO}_{3}(65 \%)$ and $1.5 \mathrm{ml}$ of $\mathrm{HCl}(37 \%)$ were added and mineralized in digester ETHOS (Milestone) for $31 \mathrm{~min}$. The obtained solution was poured into $50 \mathrm{ml}$ flasks and diluted with deionized water up to $50 \mathrm{ml}$ mark.

Lead concentration in soil and plant nutrient solution samples were analyzed by atomic absorption spectrophotometer (Buck Scientific) using 210 VGP flame method (FAAS). The obtained results were converted to the plant weight (mg/g) and processed statistically.

\section{Results}

Before experimental research, lettuce seed germination under optimum conditions was identified as $95 \%$, and under natural conditions $-90 \%$. Garden cress seed germination under optimum conditions was $94 \%$ and under natural conditions it was $89 \%$.

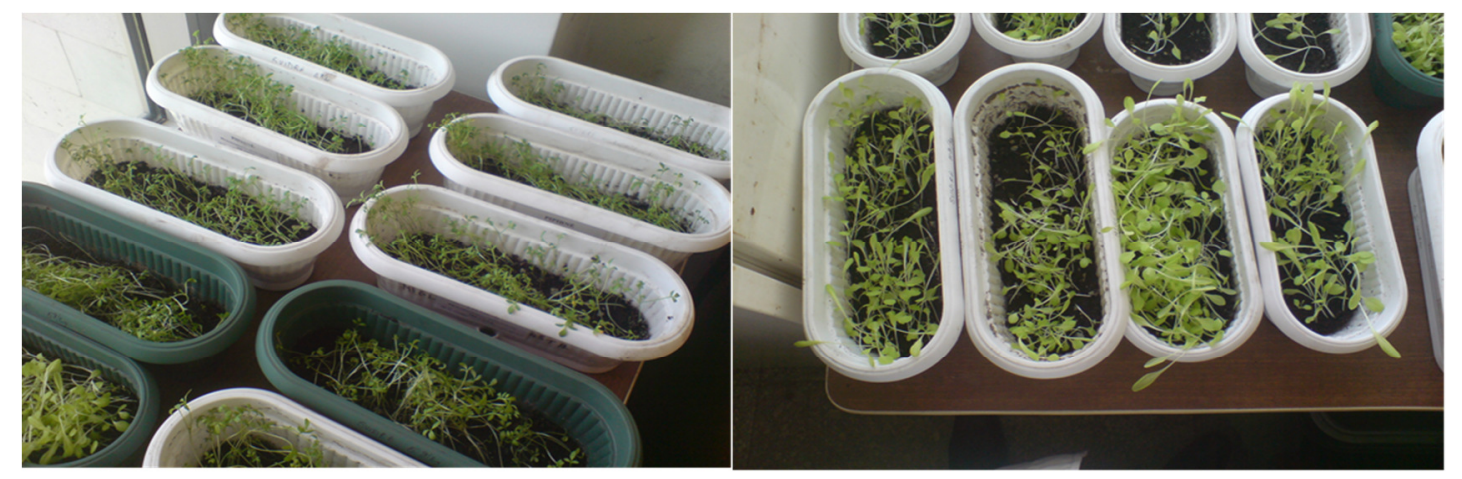

Fig. 1. The experimental plants - Lepidium sativum L. (in left), B-Lactuca sativa (in right)
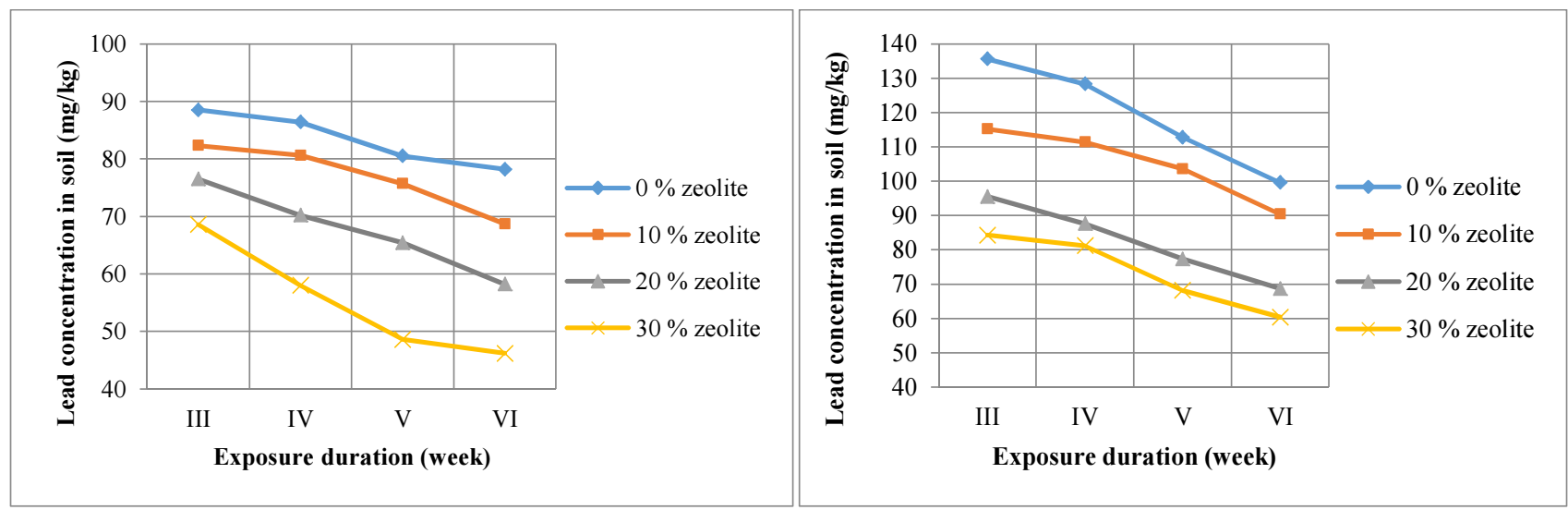

Fig. 2. The change of lead concentration in the soil with inserted zeolite when the soil was polluted with 100 ( $\mathrm{mg} / \mathrm{kg}$ ) of lead (in left), and $150(\mathrm{mg} / \mathrm{kg})$ of lead (in right); lettuce has been growing there 
The research of $100 \mathrm{mg} / \mathrm{kg}$ of lead $(\mathrm{Pb})$ change in the soil with inserted different zeolite content (Fig. 2, left) shows that $\mathrm{Pb}$ concentration in soil where lettuce was grown for six weeks reduced, as part of lead entered the zeolite, and the other part was sorbed by lettuce. Lead concentration within 4 weeks of the research reduced from $89 \mathrm{mg} / \mathrm{kg}$ to $78 \mathrm{mg} / \mathrm{kg}$ in the soil with $0 \%$ zeolite. The greatest amount of $\mathrm{Pb}$ was withhold by inserted $30 \%$ zeolite content as $\mathrm{Pb}$ content in the soil was reduced from $70 \mathrm{mg} / \mathrm{kg}$ to $47 \mathrm{mg} / \mathrm{kg}$.

As it can be seen from Fig. 2 (right), lead amount has reduced from $137 \mathrm{mg} / \mathrm{kg}$ to $99 \mathrm{mg} / \mathrm{kg}$ in the soil with growing lettuce where inserted lead concentration was $150 \mathrm{mg} / \mathrm{kg}$ and $0 \%$ zeolite was inserted. While lead decreased from $82 \mathrm{mg} / \mathrm{kg}$ to $62 \mathrm{mg} / \mathrm{kg}$ in the soil with inserted $30 \%$ zeolite content. The most equally $\mathrm{Pb}$ concentration decreased in the soil with the inserted $20 \%$ zeolite.

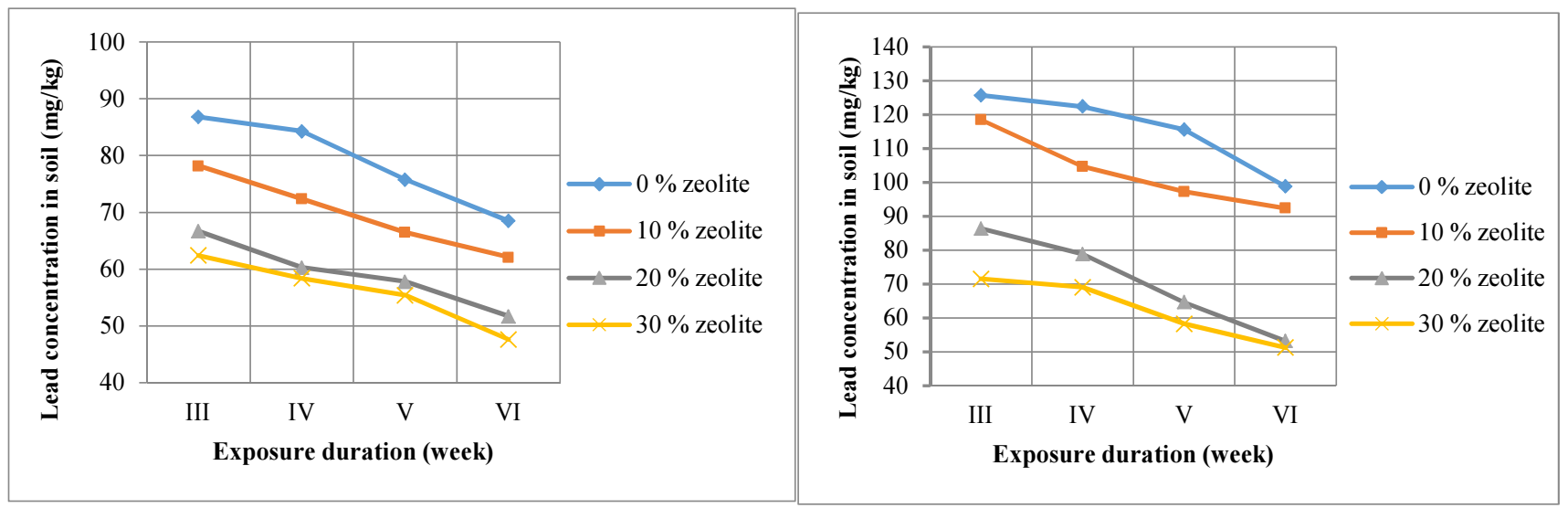

Fig. 3. The change of lead concentration in the soil with inserted zeolite when the soil was polluted with $100 \mathrm{mg} / \mathrm{kg}$ of $\mathrm{Pb}$ (in left), and $150 \mathrm{mg} / \mathrm{kg}$ of $\mathrm{Pb}$ (in right); garden cress has been growing there

$\mathrm{Pb}$ amount in soil with $0 \%$ zeolite within 4 research weeks reduced from $86 \mathrm{mg} / \mathrm{kg}$ to $69 \mathrm{mg} / \mathrm{kg}$. The greatest amount of $\mathrm{Pb}$ was detained by $30 \%$ zeolite inserted into the soil, as $\mathrm{Pb}$ content in the soil with growing garden cress reduced from $63 \mathrm{mg} / \mathrm{kg}$ to $48 \mathrm{mg} / \mathrm{kg}$ (Fig. 3, left).

$\mathrm{Pb}$ concentration in the soil with $0 \%$ of zeolite within 4 weeks of the research reduced from $122 \mathrm{mg} / \mathrm{kg} \mathrm{to} 99 \mathrm{mg} / \mathrm{kg}$. $\mathrm{Pb}$ concentration in soil with growing garden cress with $10 \%$ zeolite content decreased from $118 \mathrm{mg} / \mathrm{kg}$ to $93 \mathrm{mg} / \mathrm{kg}$. The best result was achieved for the samples with $30 \%$ zeolite, where $\mathrm{Pb}$ concentration decreased from $71 \mathrm{mg} / \mathrm{kg}$ to $54 \mathrm{mg} / \mathrm{kg}$; but the obtained samples were close to the results of the samples with $20 \%$ zeolite content (Fig. 3 , right).
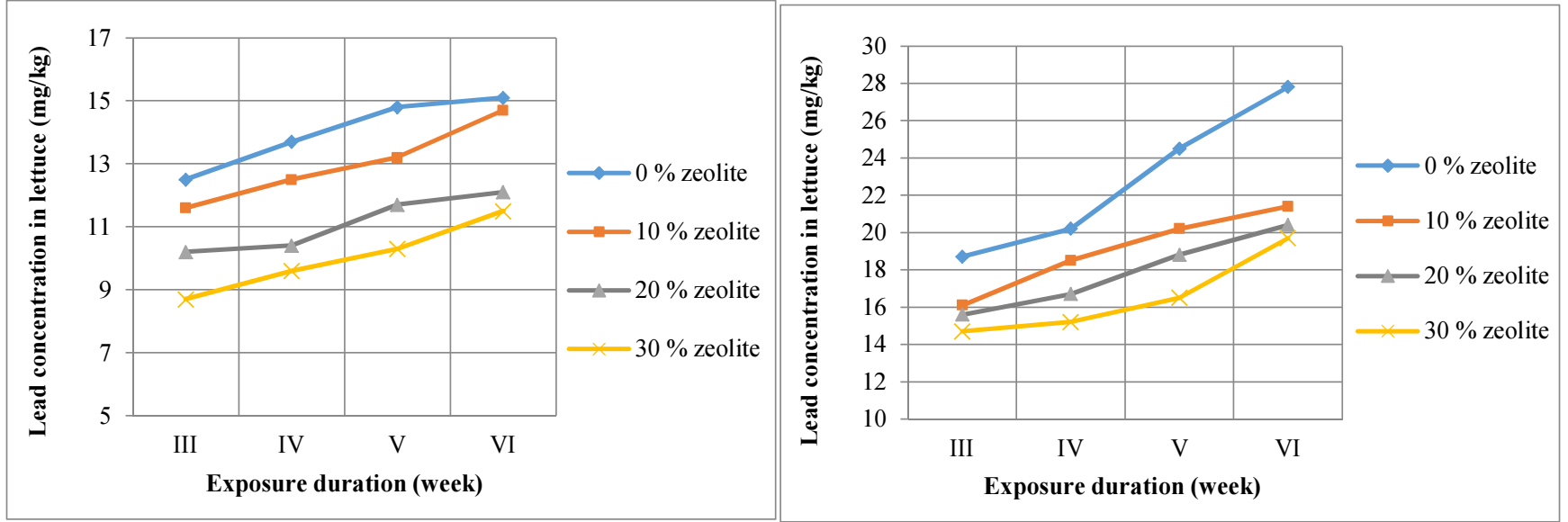

Fig. 4. Lead concentration in lettuce, growing in $100 \mathrm{mg} / \mathrm{kg} \mathrm{Pb}$ (in left), and $150 \mathrm{mg} / \mathrm{kg} \mathrm{Pb}$ (in right) polluted soil with inserted different amount of zeolite

The research of $\mathrm{Pb}$ concentration change in lettuce show (Fig. 4, left) that lettuce has sorbed different amounts of lead, depending on former zeolite content in soil during 4-week growth period. The greater the amount of zeolite was added to the soil (max $30 \%$ of the soil volume), the lower $\mathrm{Pb}$ amount has accumulated in lettuce. The greatest amount of $\mathrm{Pb}$ (from $12.2 \mathrm{mg} / \mathrm{kg}$ and $14.3 \mathrm{mg} / \mathrm{kg}$ ) was sorbed by lettuce, grown in the soil with inserted $0 \%$ zeolite content.

Figure 4 (right) shows that the concentration of $\mathrm{Pb}$ has changed the most evenly in lettuce, grown in the soil with $10 \%$ zeolite content. The minimum amount of $\mathrm{Pb}$ was sorbed by lettuce, grown in the soil with inserted $30 \%$ zeolite content (from $14.9 \mathrm{mg} / \mathrm{g}$ to $18.6 \mathrm{mg} / \mathrm{g}$ ). 

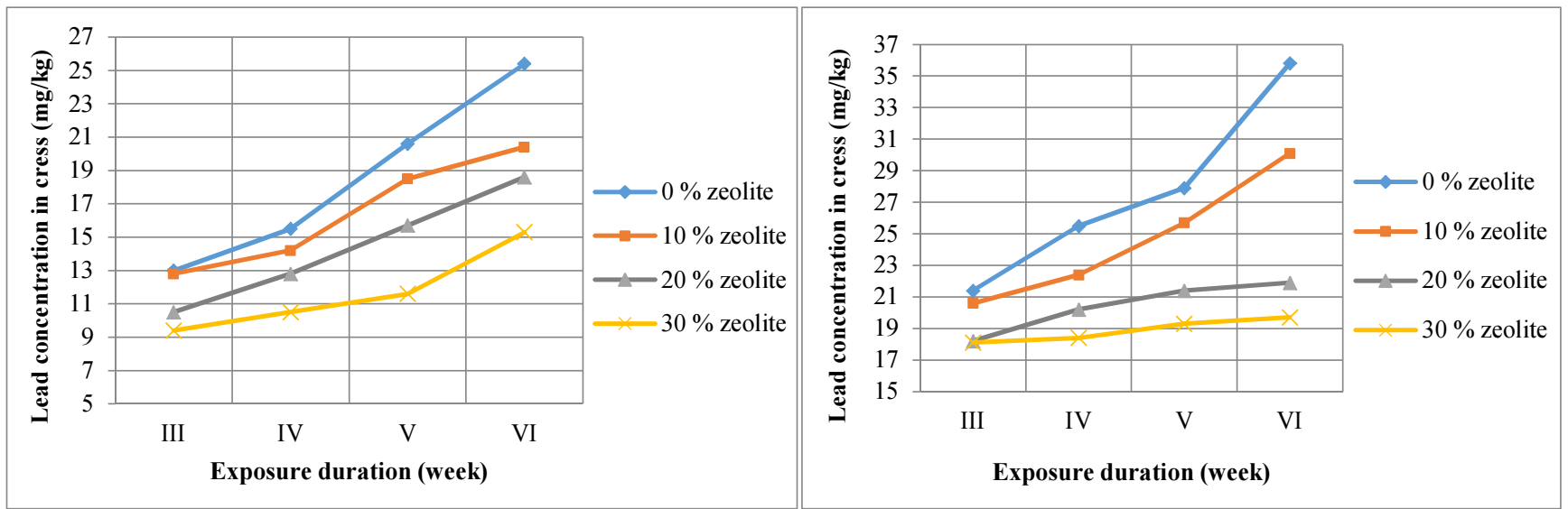

Fig. 5. Lead concentration in garden cress, growing in $100 \mathrm{mg} / \mathrm{kg} \mathrm{Pb}$ (in left), and $150 \mathrm{mg} / \mathrm{kg} \mathrm{Pb}$ (in right) polluted soil with inserted different amount of zeolite

Garden cress sorbs significantly smaller amounts of $\mathrm{Pb}$ until the fourth week of growth. Garden cress sorbed from $12.8 \mathrm{mg} / \mathrm{kg}$ to $20.4 \mathrm{mg} / \mathrm{kg} \mathrm{Pb}$ from the soil with inserted $10 \%$ zeolite content (Fig. 5, left).

The greatest amount of $\mathrm{Pb}$ was sorbed by garden cress growing in soil with inserted $0 \%$ zeolite content (from $21.4 \mathrm{mg} / \mathrm{kg}$ to $35.8 \mathrm{mg} / \mathrm{kg}$ ). The obtained results showed a smooth distribution of $\mathrm{Pb}$ concentration in garden cress that was growing in soil with $20 \%$ (from $18.2 \mathrm{mg} / \mathrm{kg}$ to $21.9 \mathrm{mg} / \mathrm{kg}$ ) and $30 \%$ zeolite content (from $18.1 \mathrm{mg} / \mathrm{kg}$ to $19.3 \mathrm{mg} / \mathrm{kg}$ ). In this case, the sorption capacity of inserted into the soil $30 \%$ zeolite differed only in the margin of errors from the sorbtion capacity of inserted into the soil $20 \%$ zeolite content (Fig. 5, right).

\section{Conclusions}

1. Heavy metal lead was absorbed from the soil by researched nutritional plants during their growth. Garden cress absorbed about $10-15 \% \mathrm{~Pb}$ more than lettuce during a six-week period of growth.

2. Natural zeolite reduces lead migration into food crops, absorbing it. Zeolite absorbed the amount of Pb from the soil at the maximum of $48 \%$ depending on the inserted content.

3. $10 \%$ zeolite content, inserted to the soil polluted with $150 \mathrm{mg} / \mathrm{kg}$ of $\mathrm{Pb}$, does not clean soil pollution to the maximum allowed contamination $(100 \mathrm{mg} / \mathrm{kg})$. The optimum amount of zeolite, cleaning the polluted soil up to MAC values are $20 \%$ of the soil volume. This assumption is supported by the other investigations [29] and the results obtained by the other researchers [25-27].

4. The inserted $30 \%$ zeolite content into the polluted soil did not gave the expected result for cleaning from lead, since the cleaning efficiency differed only $5-8 \%$ from $20 \%$ inserted to the soil zeolite content. Therefore, it is inappropriate to use $30 \%$ zeolite content of the soil amount for cleaning the soil from lead concentrations and for nutritional plant biometric factors improvement.

\section{References}

[1] Jankaitè, A.; Baltrènas, P.; Kazlauskienè, A. 2008. Heavy metal concentrations in roadside soils of Lithuania's highways, Geologija 50(64)): 237-245.

[2] Mikalajūnè, A.; Jakučionytė, L. 2011 Investigation into heavy metal concentration by the gravel roadside, Journal of Environmental Engineering and Landscape Management 19(1): 89-100. http://dx.doi.org/10.3846/16486897.2011.557474

[3] Baltrènas, P.; Kazlauskienè, A.; Mikalajūnè, A. 2012. Roads Environment Protection. Monograph. VGTU Press Technika. 384 p.

[4] Kazlauskienè, A.; Valentukevičienè, M.; Ignatavičius, G. 2013. Sustainability assessment of heavy metals and roads maintenance salts in sweep sand from roadside environment, Technological and Economic Development of Economy 19(2): 224-236. http://dx.doi.org/10.3846/20294913.2013.796500

[5] Baltrènaite, E.; Lietuvninkas, A.; Baltrènas, P. 2012. Use of dynamic factors to assess metal uptake and transfer in plants - example of trees, Water Air Soil Pollution 223: 4297-4306. http://dx.doi.org/10.1007/s11270-012-1192-7

[6] Vosylienè, M. Z.; Jankaitè, A. 2006. Effect of heavy metal model mixture on rainbow trout biological parameters, Ekologija 4: 12-17.

[7] Vosylienè, M. Z.; Kazlauskienè, A.; Mikalajūnè, A. 2010. Alterations in selected haematological parameters of rainbow trout Oncorhynchus mykiss exposed to complex mixtures of contaminants, Environment Protection Engineering 36(4): 95-104.

[8] Fatokia, O. S. 1996. Trace zinc and copper concentration in roadside surface soils and vegetation-measurement of local atmospheric pollution in Alice, South Africa Environment International 22(6): 759-762. http://dx.doi.org/10.1016/S0160-4120(96)00068-2

[9] A. K. K. Achakzai, Z. A. Bazai, S. A. Kayani. 2011. Accumulation of heavy metals by lettuce (Lactuca sativa) irrigated with different levels of wastewater of Quetta city, Pakistan Journal of Botany 43(6): 2953-2960.

[10] Culbard, E. B.; Thornton, I.; Watt, J.; Wheatley, M.; Moorcroft, S.; Thompson, M. 1988. Metal contamination in British urban dusts and soils, J Environ Qual 17: 226-234. http://dx.doi.org/10.2134/jeq1988.00472425001700020011x

[11] Čeburnis, D.; Šakalys, J.; Armolaitis, K.; Valiulis, D.; Kvietkauskas, K. 2002. In-stack emissions of heavy metals estimated by mass biomonitoring method and snow-pack analysis, Atmospheric Environment 36: 1465-1474. http://dx.doi.org/10.1016/S1352-2310(01)00577-5

[12] Mungur, A. S.; Shutes, R. B. E.; Revitt, D. M.; House, M. A. 1995. An assessment of metal removal from highway runoff by a natural wetland, Water Sci Technol 32(3): 169-75. http://dx.doi.org/10.1016/0273-1223(95)00617-6 
[13] Hares, R. J.; Ward, N. I. 1999. Comparison of the heavy metal content of motorway stormwater following discharge into wet biofiltration and dry detention ponds along the London Orbital (M25) motorway, Sci Total Environ 235: 169-78. http://dx.doi.org/10.1016/S0048-9697(99)00210-7

[14] Shutes, R. B. E.; Revitt, D. M.; Lagerberg, I. M.; Barraud, V. C. E. 1999. The design of vegetative constructed wetlands for the treatment of highway runoff, Sci Total Environ 235: 189-97. http://dx.doi.org/10.1016/S0048-9697(99)00212-0

[15] Li, X.; Poon, Ch.; Liu, P.S. 2001. Heavy metal contamination of urban soils and street dusts in Hong Kong, Applied Geochemistry 16(11-12): 13611368. http://dx.doi.org/10.1016/S0883-2927(01)00045-2

[16] Baltrènaitè, E.; Butkus, D. 2007. Modeling of Cu, Ni, Zn, Mn and Pb transport from soil to seedlings of coniferous and leafy trees, Journal of Environmental Engineering and Landscape Management 15(4): 200-207.

[17] Watt, J.; Thornton, I.; Cotter-Howells J. 1993. Physical evidence suggesting the transfer of soil Pb into young children via hand-to-mouth activity. Appl Geochem. S2: 269-72. http://dx.doi.org/10.1016/S0883-2927(09)80048-6

[18] Olajirea, A. A.; Ayodelea, E. T. 1997. Contamination of roadside soil and grass with heavy metals, Environment International 23(1): 91-101. http://dx.doi.org/10.1016/S0160-4120(96)00080-3

[19] Sebastiani, L.; Di Baccio, D.; Borghi, M.; Minnocci, A.; Tognetti, R. 2006. Uptake and translocation of Zn and Cu in poplar. 1st scientific meeting of WG1 Root to shoot translocation of pollutants and nutrients in 22-24 June, 2006 in Santiago de Compostela (Spain). Abstract book, p. 34.

[20] Brannvall, E.; Kazlauskienè, A. 2005. Experimental research on sorption of $\mathrm{Pb}^{2+}, \mathrm{Zn}^{2+}, \mathrm{Cu}^{2+}, \mathrm{Mn}^{2+}, \mathrm{Ni}^{2+}, \mathrm{Na}^{+}, \mathrm{Ca}^{2+}$ and $\mathrm{Cl}^{-}$from solutions on clinoptilolite, in Proceedings of $6^{\text {th }}$ International Conference "Environmental Engineering" 1: 49-53.

[21] Baltrènas, P.; Brannvall, E. 2006. Experimental investigation of a filter with natural sorbent charge for runoff cleaning from heavy metals and petroleum products, Journal of Environmental Engineering and Landscape Management (14)1: 31-36.

[22] Mažeikienè, A.; Valentukevičienè, M.; Jankauskas, J. 2010. Laboratory study of ammonium ion removal by using zeolite (clinoptilolite) to treat drinking water, Journal of Environmental Engineering and Landscape Management 18(1): 54-61. http://dx.doi.org/10.3846/jeelm.2010.07

[23] Mažeikienè, A.; Rimeika, M.; Valentukevičienè, M.; Oškinis, V.; Paškauskaite, N.; Brannvall, E. 2005. Removal of petroleum products from water using natural sorbent zeolite, Journal of Environmental Engineering and Landscape Managing 13(4): $187-192$.

[24] Flanigen, E. M. 1984. Adsorption properties of molecular sieve zeolites, in Zeo-agriculture: use of natural zeolites in agriculture and aquaculture. Ed. by W.G. Pond and F.A. Mumpton. Westview Press, Boulder, Colorado, p. 55-69.

[25] Šikšnianienė, J. B.; Duchovskis, P.; Bundinienè, O.; Brazaitytė, A. 2006. Skirtingu azoto trąšu formų ir ceolito įtaka burokèliu pasèlio fotosintezės rodikliams, Sodininkystè ir daržininkystè 25(1): 116-122.

[26] Šikšnianienè, J. B.; Duchovskis, P.; Bundinienè, O.; Brazaitytė, A.; Stepulaitienė, I. 2007. Skirtingu azoto trašu formu ir ceolito itaka morku fotosintezès rodikliams, Sodininkystè ir daržininkystè 26(1): 142-148.

[27] Jankauskienè, J.; Brazaitytė A. 2007. Durpių bei durpių ir ceolito substratu poveikis pomidoru produktyvumui, Sodininkysté ir daržininkystė 26(1): 119-126.

[28] Kwabena Awere Gyekye. 2013. An assessment of toxic in urban soils using garden cress (Lepidium sativum) in Vasileostrovsky Ostrov and Elagin Ostrov, Saint Petersburg, Russia, Journal of Geography and Geology 5(4): 63-70. http://dx.doi.org/10.5539/jgg.v5n4p63

[29] Baltrènas, P.; Kazlauskienè, A. 2007. Grass vegetation dynamics in soil contaminated with salt, Ekologija 53(3): 58-63.

[30] Jankaite, A.; Vasarevičius, S. 2007. Use of grassy plants to decontaminate soil from heavy metals, Ekologija 53(4): 84-89.

[31] Butkus, D.; Baltrènaitè, E. 2007. Transport of heavy metals from soil to Pinus sylvestris L. and Betula pendula trees, Ekologija 53(1): 29-36. 